\title{
KEBIJAKAN PENGELOLAAN LINGKUNGAN DI KAWASAN KENDENG UTARA PROVINSI JAWA TENGAH
}

\author{
Hartuti Purnaweni 1 \\ 1 Jurusan Administrasi Publik, FISIP, Universitas Diponegoro \\ M agister dan Doktor Administrasi Publik, FISIP, U niversitas Diponegoro \\ Magister dan D oktor IImu Lingkungan U niversitas Diponegoro \\ hartutipurnaweni@gmail.com
}

\section{ABSTRAK}

Kebijakan tentang pengelolaan lingkungan hidup di Indonesia mengalami perubahan dengan dikeluarkannya Undang-undang Nomor 32 Tahun 2009 tentang Perlindungan dan Pengelolaan Lingkungan Hidup. Keluarnya Undang-undang ini adalah karena dirasakan kerusakan lingkungan makin menjadi, sehingga perlu dikeluarkan sebuah kebijakan yang tidak hanya mengharuskan pengelolaan lingkungan akan tetapi juga perlindungan terhadap lingkungan. Tujuan penelitian ini adalah : (1) mengetahui tentang kebijakan lingkungan kawasan karst Kendeng Utara di Kecamatan Sukolilo, Kabupaten Pati, Provinsi Jawa Tengah; (2) mengetahui pengelolaan lingkungan di kawasan karst Kendeng Utara, Kecamatan Sukolilo, Kabupaten Pati, Provinsi Jawa Tengah.

Metode penelitian ini adalah deskriptif kualitatif, dengan lokasi penelitian khususnya di Kecamatan Sukolilo, Kabupaten Pati, Provinsi Jawa Tengah, karena di wilayah ini terutama terjadi pertentangan kepentingan terhadap pengelolaan lingkungan di kawasan karst Kendeng Utara. Kesimpulan penelitian adalah: (1) Kebijakan pengelolaan kawasan karst di Kecamatan Sukolilo terwujud dalam Peraturan Menteri dan Keputusan Gubernur Jawa Tengah, terkait dengan karakteristik geografis. (2) Pengelolaan lingkungan memenuhi tiga unsur POAC (Planning, Organizing, Actuating) yang menjadi fokus penelitian ini. Rekomendasinya adalah : (1) Kebijakan kawasan karst sebaiknya mempertimbangkan keunikan keunikan kawasan karst, kondisi sosial ekonomi sebagian masyarakat yang masih bersifat tradisional, dan dukungan publik perlu digalang oleh pemerintah untuk dilakukannya pembangunan yang seharusnya menguntungkan semua pihak, dan mengacu pada pembangunan berkelanjutan; (2) Pengelolaan lingkungan: (a) Planning/ Perencanaan: pembangunan berkelanjutan seharusnya dikedepankan, dengan menekankan pada terwujudnya pembangunan sosial dimana peranserta dan keadilan menjadi bagian penting dalam pembangunan; (b) Organizing/Pengorganisasian: kepentingan yang bersinggungan dalam pengelolaan kawasan karst antara pemerintah, swasta, dan masyarakat, yang seharusnya dilakukan dengan mengedepankan winwin solution, misalnya dengan pelaksanaan zonasi; (c) Actuating/Pelaksanaan: harus dimunculkan pelaksanaan optimatisasi pemanfaatan sumberdaya alam secara efisien, dengan memanfaatkan teknologi yang ramah lingkungan, sekiranya pabrik semen jadi didirikan di wilayah Sukolilo.

Kata kunci : kebijakan, lingkungan, kawasan karst, Kendeng Utara.

\section{ABSTRACT}

Policy on environmental management in Indonesia is changed with the issuance of Law No 32 Year 2009 on Environmental Management and Protection. The issuance of this law is based on the worsening condition of the environment. The aim of this research is to: (1) analyzing the policy on karst area policy in Kendeng Utara, Sukolilo District, Pati Regency, Central Java; (2) analyzing environmental management in Kendeng Utara karst area, Sukolilo District, Pati Regency, Central Java.

Research method is descriptive qualitative, with research location at Sukolilo District, Pati Regency, Central Java, since there is an inter esting interest conflict on environmental management in Kendeng area. Summary of this research: (1) There are several policies on karst area in Sukolilo are based on its geographical characteristics; (2) Environmental management have conformed three out of POAC aspects as focus of this research, namely Planning, Organizing, Actuating. Recommendation: (1) Environmental management should be based on karst area uniqueness, socio economic condition of the local people, and the need of public support for the government for sustainable development; (2) Environmental Management: a) Planning: focus on sustainable development, by creating social 
development in which local people's involvement and fairness are parts of development parts; b) Organizing: the stakeholders' inter est should be managed with win-win solution, such as by zonation; c) Actuating: optimatization of efficient natural resources management by using environmentally friendly technology should the cement factory is built in Sukolilo.

Keywords: policy, environment, karst, Kendeng Utara

\section{LATAR BELAKANG}

Perubahan paradigma pembangunan di Indonesia diawali dengan berlakunya Undang-undang Nomor 4 Tahun 1882 tentang Pokok-pokok Lingkungan Hidup, yang memberikan pedoman sehingga muncul pemahaman yang jelas dan seragam antar para pemangku kepentingan mengenai lingkungan hidup. Undang-undang ini kemudian berkembang menjadi UndangUndang Nomor 23 Tahun 1997 tentang Pengelolaan Lingkungan Hidup, yang memberikan arahan untuk kegiatan pengelolaan lingkungan hidup di Indonesia.

Kemudian kebijakan tentang pengelolaan lingkungan hidup di Indonesia mengalami perubahan dengan dikeluarkannya Undang-undang Nomor 32 Tahun 2009 tentang Perlindungan dan Pengelolaan Lingkungan Hidup. Keluarnya Undang-undang ini adalah karena dirasakan kerusakan lingkungan makin menjadi, sehingga perlu dikeluarkan sebuah kebijakan yang tidak hanya mengharuskan pengelolaan lingkungan akan tetapi juga perlindungan terhadap lingkungan.

Inti dikeluarkannya kebijakan publik itu adalah diharapkan terjadi perubahan paradigma pembangunan dari yang bertumpu pada pertumbuhan yang berfokus pada kepentingan ekonomi, menjadi bertumpu pada pembangunan berkelanjutan. Perubahan paradigma ini tentunya sangat menuntut kinerja penyelenggaraan Pemerintahan Daerah yang lebih baik, dengan harapan dapat lebih memperhatikan pengelolaan lingkungan yang lebih baik pula, karena itulah sumber jaminan keberlanjutan pembangunan.

Pengelolaan lingkungan merupakan hal yang sangat penting dilakukan, mengingat bahwa manusia selalu berusaha memaksimalkan segala perwujudan keinginannya dan seringkali dengan cara yang secepat-cepatnya, sehingga cenderung mengorbankan kepentingan lingkungan hidupnya.

Kegiatan penambangan mengakibatkan munculnya banyak permasalahan lingkungan. Salah satu masalah yang timbul akibat kegiatan penambangan adalah dilakukannya penambangan kapur di kawasan karst, sebagaimana dilaporkan dalam hasil penelitian Suhartadi (2009) dan Wuspada (2012). Suhartadi menulis tentang "Evaluasi Pengelolaan Lingkungan Kegiatan Penambangan Batu Kapur PT. Sinar Alfa Fortuna (NAF) di Rembang", sementara Wuspada menulis tentang "Implementasi Kebijakan Pelarangan Penambangan di Kawasan Karst Kabupaten Gunung Kidul”.

Salah satu sarana pemenuhan kebutuhan manusia adalah dengan penambangan berbagai bahan tambang, yang bisa dimanfaatkan untuk melakukan berbagai aktivitas. Namun pemanfaatan yang berlebih dapat membahayakan karena penambangan pasti mengubah bentang alam secara signifikan, dan dengan demikian sangat berpotensi merusak lingkungan. Dengan demikian juga meningkatkan resiko bencana alam, yang kerugiannya bahkan dapat mengalahkan kemanfaatan yang dapat dipetik dari kegiatan penambangan.

Dari sisi administrasi publik, hal ini patut diwaspadai. Harus dimunculkan sense of urgency terutama di kalangan unsur-unsur pemerintahan terhadap rangkaian bencana yang kemungkinan akan terjadi, apabila kawasan yang rawan bencana terus menerus dieksploitasi. Aparat pemerintah perlu mempunya sense of crisis dan mempraktekkannya dalam tugas keseharian mereka. Ketika 
bencana sudah dalam ada dalam bayangan mereka, maka pelaksanaan tugas dengan cara business as usual tidak dapat lagi diterapkan.

\section{PERUMUSAN MASALAH}

Penelitian tentang "Kebijakan Pengelolaan Lingkungan di Kawasan Kendeng Utara, Provinsi Jawa Tengah" ini bermaksud mengetahui tentang: (1) Bagaimanakah kebijakan lingkungan kawasan karst Kendeng Utara di Kecamatan Sukolilo, Kabupaten Pati, Provinsi Jawa Tengah? (2) Bagaimanakah pengelolaan lingkungan di kawasan karst Kendeng Utara, di Kecamatan Sukolilo, Kabupaten Pati, Provinsi Jawa Tengah?

\section{TINJAUAN PUSTAKA}

Kebijakan publik merupakan kebijakan yang dibuat oleh badan-badan dan pejabat pemerintah, yang bertujuan untuk menyelesaikan berbagai masalah yang dihadapi publik. Penyelesaian masalah menyangkut berbagai hal, di antaranya adalah masalah alokasi, sebagaimana menurut pendapat Keban (2003:56-57) yang mengutip Peters yang menyatakan bahwa kebijakan publik adalah aksi pemerintah dalam menghadapi masalah, dengan mengarahkan perhatian terhadap alokasi. Alokasi di sini dengan demikian menyangkut sumberdaya. Kebijakan publik adalah pemanfaatan sumberdayasumberdaya yang ada untuk memecahkan masalah-masalah publik atau pemerintah.

\section{Kebijakan Publik}

"Masalah publik dan pemerintah" di sini lebih meliputi masalah-masalah sosial, sebagaimana dinyatakan oleh Harold D. Laswell dan dikutip oleh Nugroho (2003) yang menyatakan bahwa kebijakan publik "...refers to governmental decisions designed to deal with various sosial problems, such as those related to foreign policy, environmental protection, crime, unemployment, and numerous other sosial problems". Permasalahan yang menyangkut hubungan luar negeri, pelestarian lingkungan, dan kriminalitas, hanyalah bagian dari permasalahan sosial yang tak terhitung banyaknya yang mengganggu kehidupan masyarakat sehingga negara perlu turun tangan untuk menyelesaikannya. Tanpa kebijakan publik, maka rakyat tidak akan bertindak untuk mengatasinya, dengan cara-cara yang diinginkan oleh pemerintah.

Dari berbagai literatur dan penjelasannya tersebut, bisa disimpulkan bahwa definisi kebijakan publik kurang lebih adalah "serangkaian tindakan yang dipilih dan atau dilakukan oleh pemerintah atau negara secara paksa (sah) kepada seluruh anggota masyarakat, yang mempunyai tujuan tertentu demi memecahkan masalahmasalah publik". Dengan demikian kebijakan publik dibuat dengan maksud untuk mengatasi masalah publik.

\section{Pengelolaan Lingkungan}

Pengelolaan lingkungan hidup merupakan usaha pemanfaatan sumberdaya, namun yang berciri khas yaitu merupakan upaya terpadu pelestarian fungsi limgkungan hidup yang meliputi kebijakan penataan, pemanfaatan, pengembangan, pemeliharaan, pemulihan, pengawasan, dan pengendalian lingkungan hidup. Hal ini sebagaimana yang tertulis dalam Undangundang Nomor 32 Tahun 2009 tentang Perlindungan dan Pengelolaan Lingkungan Hidup.

Prinsip pengelolaan lingkungan suatu wilayah dapat dilakukan dengan menggunakan empat indikator POAC yaitu Planning, Organizing, Actuating dan Controlling (Asdak, 2004).

Adapun penjelasannya adalah sebagai berikut: (1) Planning atau Perencanaan adalah kegiatan perencanaan yang disusun dalam rangka pengelolaan lingkungan secara terpadu terhadap suatu wilayah; (2) Organizing (Pengorganisasian), yaitu pelaksanaan kegiatan pengelolaan lingkungan suatu wilayah secara efektif dan efisien, dalam arti masing-masing pihak yang terlibat dapat menjalankan tugasnya dengan baik dan bertanggungjawab; (3) Actuating 
(Pelaksanaan). Pada tahap pelaksanaan, program-program yang dirancang harus menunjukkan adanya: optimatisasi pemanfaatan sumberdaya alam secara efisien, dorongan pelaksanaan konservasi sumberdaya alam dalam penambangan, meningkatnya peran stakeholders dan kelembagaan yang terlibat.

\section{Kawasan Karst}

Faida dkk menulis bahwa karst merupakan istilah dalam bahasa Jerman yang diturunkan dari bahasa Slovenia kras, yang berarti lahan gersang berbatu. Istilah ini di Slovenia sebenarnya tidak terkait dengan batu gamping dan proses pelarutan, namun saat ini istilah karst telah diadopsi untuk istilah bentuk lahan hasil proses pelarutan. Mendengar "karst" maka yang terbayang adalah lahan berwarna putih kekuningan atau kecoklatan yang mudah menyerap air.

Adapun Ford dan Wiliams dikutip oleh Wuspada (2011) mendefinisikan karst sebagai medan dengan kondisi hidrologi khas sebagai akibat dari batuan yang mudah larut dan mempunyai porositas sekunder yang berkembang baik. Karst dicirikan oleh: (i) terdapatnya cekungan tertutup dan atau lembah kering dalam berbagai ukuran dan bentuk, (ii) langka atau tidak terdapatnya drainase/ sungai permukaan, dan (iii) terdapatnya goa dari sistem drainase bawah tanah.

Kawasan karst merupakan wilayah yang dapat menangkap dan menyimpan air hujan, sebagai habitat bagi beberapa spesies makhluk hidup khusus, dan berpotensi pertambangan karena fisiografi berbukit-bukit yang terbentuk dari batu gamping

\section{METODE PENELITIAN}

Penelitian ini mempergunakan metode deskriptif kualitatif. Subyek penelitian terkait dengan Kebijakan Pengelolaan lingkungan di lingkungan Jawa Tengah. Pada penelitian ini, aspekaspek yang dikaji adalah : (1) Kebijakan kawasan karst di Kawasan Kendeng Utara, khususnya di Kecamatan Sukolilo, Kabupaten Pati, Provinsi Jawa Tengah;
(2) Pengelolaan lingkungan di Kawasan Kendeng Utara, khususnya di Kecamatan Sukolilo, Kabupaten Pati, Provinsi Jawa Tengah. Lokasi penelitian ini adalah di lingkungan kawasan Kendeng Utara, yaitu di Kabupaten Pati, dan khususnya di wilayah Kecakatan Sukolilo, karena di wilayah ini terutama terjadi pertentangan kepentingan terhadap pengelolaan lingkungan dengan rencana didirikannya pabrik semen yang mendapat protes keras dari masyarakat setempat.

Ada dua jenis data yang dimanfaatkan dalam penelitian ini, yaitu data primer dan data sekunder, dengan rincian sebagai berikut: (1) Data Primer : pengambil kebijakan di tingkat Provinsi Jawa Tengah, yaitu Dinas Energi dan Sumber Daya Mineral (ESDM) dan Dinas Kehutanan; pengambil kebijakan di Kabupaten Pati (BLH Kabupaten Pati), masyarakat di lingkungan Kecamatan Sukolilo Kabupaten Pati khususnya komunitas Sedulur Sikep, serta para ahli lingkungan yang mempunyai pengetahuan dan kepedulian tentang/terkait kawasan karst Kendeng Utara. (2) Data Sekunder: berupa data tertulis mencakup peraturan-peraturan maupun laporanlaporan, arsip, gambar, dokumen, ataupun catatan-catatan, khususnya dari instansi-instansi pemerintah yang ada kaitannya dengan fokus kajian penelitian. Selain itu berbagai buku pustaka/ literatur yang terkait dengan topik penelitian ini. Teknik pengambilan data dengan melalui observasi, wawancara mendalam, dan telaah bahan sekunder. Data kualitatif dianalisis dengan pendekatan analisis kualitatif bersifat deskriptif, lebih banyak dikenal dengan metode pendekatan analisis deskriptif kualitatif (Brannen, 2005).

\section{GAMBARAN UMUM WILAYAH}

Kabupaten Pati merupakan satu dari 35 kabupaten/ kota di Provinsi Jawa Tengah yang mempunyai letak cukup strategis karena dilewati oleh jalan nasional yang menghubungkan kota-kota besar di pantai utara Pulau Jawa. Kabupaten Pati secara administratif dibagi menjadi 21 kecamatan, 401 desa dan 5 kelurahan. Kecamatan dengan 
wilayah terluas adalah Kecamatan Sukolilo (15.874 ha), dengan Kecamatan Wedarijaksa memiliki luas wilayah terkecil (4.085 Ha). Menurut klasifikasi Tingkat Perkembangan Desa semua sudah menjadi desa/ kelurahan kategori III (Desa Swasembada).

$$
\text { Kondisi topografi dan }
$$

morfologinya didominasi oleh pegunungan kapur yang membujur di sebelah selatan meliputi sebagian kecil wilayah Sukolilo, Kayen, Tambakromo, Winong, dan Pucakwangi. Kabupaten Pati mempunyai luas wilayah $1.503 .680 \mathrm{Ha}$ yang terdiri dari 59.332 ha lahan sawah, 66. 086 ha lahan bukan pertanian. Dengan luas wilayah terbesar adalah Kecamatan Sukolilo dengan luas 15. 874 Ha dan luas wilayah terkecil adalah Kecamatan Wedarijaksa dengan luas $4.085 \mathrm{Ha}$.

Penduduk Kabupaten Pati tahun 2012 sebanyak 1.207.399 jiwa yang terdiri dari penduduk laki-laki sebesar 586.870 jiwa dan penduduk perempuan sebesar 620.529 jiwa. kepadatan penduduk Kabupaten Pati berada di kisaran 802. 96 jiwa/ $\mathrm{km}^{2}$ lebih tinggi dibanding tahun sebelumnya sebesar 797.06 jiwa/ km². Berdasarkan data mengenai tingkat pendidikan di Kecamatan Sukolilo dapat diketahui bahwa tingkat pendidikan terakhir di Kecamatan tersebut paling banyak adalah lulus SD.

Mata pencaharian tertinggi masyarakat di Kecamatan Sukolilo adalah bekerja sebagai petani pemilik dengan jumlah sebesar 23.584. Desa Baturejo merupakan desa dengan jumlah petani pemilik paling tinggi yaitu 3.474 jiwa. Buruh tani berada di urutan kedua mata pencaharian paling banyak di Kecamatan Sukolilo dengan jumlah sebesar 23.281 jiwa atau hanya selisih 303 jiwa dari jumlah petani pemilik. Adapun industri merupakan mata pencaharian paling kecil di Kecamatan ini dengan jumlah 6 orang saja, yaitu yang berada di desa Kuwawur.

Sebagian penduduk berprofesi sebagai petani di lahan sawah dan non sawah. Kondisi lahan pertanian penduduk di sekitar Pegunungan Kendeng berupa sawah tadah hujan dan tegalan. Kondisi sawah cukup subur, biasanya bisa dua kali musim padi dan satu kali polowijoPada tegalan milik penduduk atau tanah tanah terbuka di sekitar pemukiman atau sawah, dapat dijumpai berbagai jenis tanaman mulai dari tanaman kayu seperti jati, mahoni, randu, bambu, serta tamanan polowijo berupa jagung atau ketela pohon dan berbagai jenis sayur. Masyarakat juga menanam pohon jati, di tegalan atau di lahan-lahan terbuka milik penduduk.

Kondisi tanaman jati milik penduduk ini secara umum tumbuh dengan baik dan subur, bahkan di beberapa wilayah lebih rimbun, rapat, dan hijau daripada di lahan milik Perhutani. Mengapa demikian? Menurut beberapa informan kunci yang diwawancarai, ternyata masyarakat merasa bahwa lahan milik Perhutani adalah lahan milik Negara, yang merupakan milik bersama, sehingga mereka cenderung merasa tidak bersalah seandainya "memanfaatkan" kayukayunya untuk kebutuhan mereka. Sementara itu, lahan milik pribadi terlindungi, karena masyarakat mengganggap itu merupakan hak milik perseorangan sehingga tidak dapat dimanfaatkan dengan bebas karena bukan merupakan milik bersama.

Selain itu, di kawasan Sukolilo juga ditemukan berbagai situs yang dikeramatkan penduduk, misalnya berupa kuburan para sesepuh desa serta gua-gua yang dianggap keramat. Mereka masih mengganggap kawasan tersebut harus dihormati dan dijaga baik-baik. Inilah salah satu bentuk budaya yang terkait dengan lingkungan, yang berlokasi di kawasan Sukolilo.

\section{HASI L DAN PEMBAHASAN}

Di Pulau Jawa, pegunungan karst membentang di selatan dari Ujung Kulon ke Sukabumi, Ciamis hingga Kebumen, lalu Wonosari hingga Tulung Agung. Begitu juga di bagian utara, terutama perbatasan Jawa Tengah dan Jawa Timur, dari Blora, Purwodadi, Pati, Tuban, Gresik, sampai ke Madura. Pegunungan Kendeng merupakan salah satu bagian dari kawasan ini. 


\section{Kebijakan Kawasan Karst}

Kawasan Kendeng Utara di Kabupaten Pati dicirikan oleh deretan pegunungan karst, yang merupakan bagian dari pegunungan yang membentang mulai dari Tuban di sebelah timur hingga Grobogan di sebelah barat. Sesuai dengan pendapat Sentosa dkk (2004) karst di kawasan Kecamatan Sukolilo dicirikan dengan berkembangnya kubah karst, yaitu positif yang tumpul, tidak terjal. Kawasan karst ini merupakan kawasan yang sangat penting dalam ekosistem, karena berbagai jasa lingkungan yang diberikannya, antara lain sebagai penyerap air, mencegah/mengurangi banjir, mengandung sumber air di sungai-sungai bawah tanah dan gua-guanya, dan lain sebagainya sehingga berfungsi sebagai ruang terbuka hijau.

Dari hasil observasi, kawasan karst Kendeng Utara juga menunjukkan bukti dari pendapat Haryono, dkk (2002) yang menjelaskan bahwa kawasan karst memiliki fungsi dan arti penting sebagai: (a) obyek kajian ilmu pengetahuan yang unik dan langka; (b) kawasan yang sangat sensitif terhadap keberadaan air dan sosial budaya masyarakat; (c) merupakan habitat yang mendukung keanegaraman jenis flora dan fauna yang spesifik; serta (d) memiliki fungsi dalam penyerapan karbondioksida CO2 dan atmosfer, salah satu proses alam yang dapat mencegah atau mengurangi terjadinya pemanasan global, karena karbondioksida (CO2) merupakan salah satu penyebab terjadinya pemanasan global.

Selain itu kawasan karst berfungsi sebagai ekosistem untuk habitat berbagai hewan dan tumbuhan. Kekayaan flora dan fauna kawasan karst ini luar biasa (Jumari, 2011). Dari hasil pengamatan dan wawancara dengan informan dari Dinas Kehutanan Provinsi Jawa Tengah, nampak bahwa sebagian besar kawasan Kendeng merupakan lahan hutan jati milik Perhutani, termasuk yang ada di kawasan Sukolilo. Seperti halnya Kawasan Kendeng lainnya daerah ini merupakan kawasan pegunungan dengan tanah yang berkapur dengan lapisan tanah alluvial yang ketebalannya bervariasi. Lahan ini sejak lama merupakan lahan untuk budidaya tanaman jati. Tanaman yang ada di lokasi dimonopoli oleh Jati yang sekarang ada di lokasi merupakan hasil penanaman kembali yang dilakukan sekitar tahun 2000-an, setelah sebelumnya kawasan tersebut mengalami penjarahan pada masa awal reformasi (Jumari, 2011).

Oleh karena kondisi fisik dan kekayaan flora faunanya, maka dikeluarkan berbagai kebijakan yang khas untuk kawasan karst. Kebijakan pemerintah tentang kawasan karst ini antara lain muncul dalam bentuk Undang-undang, Peraturan Menteri, Peraturan Gubernur, dan lain sebagainya.

Kebijakan yang mengenai kawasan tersebut adalah Peraturan Menteri ESDM Nomor 17 Tahun 2012 tentang Penetapan Bentang Alam Karsts. Pasal 1 Nomor 4 Peraturan Menteri ESDM Nomor 17 tahun 2012 tersebut menjelaskan bahwa "bukit karst adalah bukit dengan bentuk kerucut (conical), membulat (sinosida), menara (tower) meja (table) dan / atau bentukan lainnya". Selain terdapat bukit karst terdapat pula gua-gua dan sungai bawah tanah.

Peraturan Menteri Energi dan Sumberdaya Mineral (Permen ESDM) ini juga menyebutkan bahwa "kawasan bentang alam karst merupakan kawasan lindung geologi sebagai bagian dari kawasan lindung nasional". Masih menurut Permen ESDM Nomor 17 tahun 2012 tersebut, pada pasal 4 ayat (1) menyebutkan bahwa " kawasan bentang alam karst sebagaimana dimaksud dalam pasal 3 merupakan kawasan bentang alam karst yang menunjukkan bentuk eksokarst dan endokarst". Bentuk eksokarst yang disebutkan dalam Permen ESDM Nomor 17 Tahun 2012 pasal 4 ayat (5) terdiri atas : mata air permanen, bukit karst, dolina, uvala, polje, dan atau telaga. Sedangkan pasal 4 ayat (6) menyebutkan bahwa "bentuk endokarst terdiri atas sungai bawah tanah; dan / atau speleotem".

Selain itu, kebijakan penting untuk kawasan karst Kendeng Utara, khususnya di kawasan Sukolilo ini ada pada Peraturan Gubernur Jawa Tengah 
Nomor 128 Tahun 2008 tentang Penetapan Kawasan Lindung Karst Sukolilo. Peraturan yang terkait dengan tata ruang kawasan karst Sukolilo ini dimaksudkan sebagai sebuah cara pemataan ruang dalam kaitannya dengan lingkungan hidup (Sugandhy, 1999). Dalam kebijakan Peraturan Gubernur tersebut ditetapkan bahwa kawasan karst dibagi menjadi kawasan yang dilindungi dan kawasan yang dapat dimanfaatkan. Dalam Pasal 3 Peraturan Gubernur Jawa Tengah Nomor 128 Tahun 2008 tentang Penetapan Kawasan Lindung Karst Sukolilo tersebut dinyatakan bahwa: (1) Maksud ditetapkannya kawasan lindung kars Sukolilo adalah sebagai pedoman bagi upaya perlindungan kawasan kars Sukolilo; (2) Penetapan kawasan lindung kars Sukolilo bertujuan untuk: a) memberikan perlindungan terhadap kars Sukolilo; b) sebagai pedoman bagi pemanfaatan sumberdaya bahan tambang yang berada di kars Sukolilo tanpa mengorbankan kawasan lindung kars Sukolilo.

Peraturan Gubernur ini kemudian menimbulkan kontroversi, karena dianggap merupakan jalan bagi diberikannya ijin pendirian pabrik semen di kawasan Sukolilo karena memberikan pedoman bagi pemanfaatan sumberdaya bahan tambang di kawasan tersebur, sebagaimana dinyatakan oleh kelompok yang menentang rencana penambangan di kawasan karst Sukolilo ini.

Dari hasil wawancara mendalam, Gunretno, tokoh masyarakat asli Sedulur Sikep yang tinggal di Kecamatan Sukolilo menyatakan bahwa kelestarian lingkungan karst harusnya lebih diutamakan, untuk kepentingan pembangunan yang berkelanjutan. Meskipun jumlah masyarakat Sedulur Sikep tidak banyak dalam jumlah, namun mereka menonjol dalam suara. Akibatnya, terbentuk opini publik yang kuat bahwa masyarakat Sukolilo menolak kehadiran rencana pabrik semen Gresik di wilayah tersebut.

\section{Pengelolaan lingkungan}

Pengelolaan lingkungan bertujuan agar tercipta keberlanjutan pemba- ngunan dengan azas keterpaduan antara berbagai stakeholders, yang dalam penelitian ini mencakup tiga dari empat indikator POAC yaitu Planning, Organizing, dan Actuating.

\section{Planning (Perencanaan)}

Dalam hal ini mencakup kegiatan perencanaan dalam rangka pengelolaan lingkungan secara terpadu terhadap suatu wilayah. Perencanaan Pemerintah yang matang diharapkan dapat menghasilkan kebijakan publik yang baik bagi semua pihak dan tidak ada yang dirugikan. Kebijakan publik adalah serangkaian keputusan yang kurang lebih berhubungan (termasuk keputusan tidak berbuat) yang dibuat badan-badan atau kantor-kantor pemerintah, diformulasikan dalam bidang-bidang isu yaitu arah tindakan aktual atau potensial dari pemerintah yang di dalamnya terkandung konflik antara kelompok masyarakat.

Kebijakan publik menurut Thomas Dye dalam Subarsono (2005) adalah apapun pilihan pemerintah untuk melakukan sesuatu atau tidak melakukan sesuatu. Definisi tersebut mengandung antara lain makna bahwa kebijakan publik menyangkut pilihan yang harus dilakukan atau tidak dilakukan oleh badan pemerintah. Dalam hal ini adalah apakah pemerintah akan melakukan pemberian ijin penambangan atau tidak memberikan ijin penambangan terhadap kawasan karst di Kecamatan Sukolilo.

Penambangan batu gamping di kawasan karst amat berpotensi merusak lingkungan. Letak kawasan karst yang berada di daerah tropis menjadikan kawasan ini sebagai penyerap karbon yang potensial karena pada daerah ini curah hujan sangat tinggi. Semakin banyak curah hujan maka proses karsifikasi lebih intensif sehingga penyerapan karbon cukup tinggi, karena dalam proses karsifikasi terjadi penyerapan karbon yang berarti dapat mengurangi pemanasan global. Proses penambangan dapat menyebabkan hilangnya lapisan epikarst, yakni lapisan tipis di permukaan lahan yang menahan air. Dengan adanya kegiatan penambangan maka terjadi pengurangan 
penyerapan air dan merusak tata air serta habitat satwa endemik seperti kelelawar, ular, burung walet dan kera ekor panjang (Wuspada, 2012).

Dibutuhkan pasir untuk pembangunan fisik gedung, dibutuhkan emas untuk keperluan industri dan perhiasan yang bernilai tinggi, dibutuhkan perak untuk membuat peralatan makan dan juga perhiasan. Selain itu juga dibutuhkan semen untuk membangun tidak hanya bangunan gedung dan rumah, namun juga jalan raya karena sifat keras dan padat semen, sehingga sangat sesuai untuk terutama pembangunan jalan-jalan di kawasan yang lahannya bergerak dan mudah longsor.

Akan tetapi perlu diingat bahwa diperkirakan 30-40 persen sumber air berasal dari kawasan karst ini. Kawasan Karst merupakan ekosistem yang terbentuk dalam kurun waktu ribuan tahun, tersusun atas batuan karbonat (batu kapur atau batu gamping) yang mengalami proses pelarutan sedemikian rupa hingga membentuk kenampakan morfologi dan tatanan hidrologi yang unik dan khas. Dibutuhkan waktu puluhan juta tahun untuk membentuk gugusan terumbu karang dan mencuatkannya ke permukaan Bumi sebagai pegunungan karst. Sebaliknya, bagi pabrik semen, hanya butuh puluhan tahun untuk menghancurkan dan mengubahnya menjadi produk yang lebih diinginkan manusia, dan menghasilkan banyak uang yang merupakan faktor penarik utam dalam setiap kegiatan pembangunan yang masih bertumpu pada paradigma pertumbuhan.

Dalam hal ini perlu diingat pendapat Sudharto P.Hadi, pakar lingkungan dari Undip, yang menyatakan bahwa pembangunan memiliki arti ganda. Makna pertama adalah pertumbuhan ekonomi, yang lebih menekankan pada kuantitas produksi dan enggunaan sumber-sumber daya. Makna kedua adalah bahwa pembangunan harus memusatkan perhatian lebih pada hubungan sosial, dalam kaitannya dengan pembangunan berkelanjutan (Hadi, 1996). Pembangunan berkelanjutan seharusnya menekankan pada terwujudnya pembangunan sosial dimana peranserta, dan keadilan menjadi bagian penting dalam pembangunan. Demikian juga pembangunan yang berlaku pada kawasan karst Sukolilo. Hadi menjadi salah satu informan dalam penelitian ini, sebagai penggagas Forum Tata Ruang Jawa Tengah, yang mendiskusikan berbagai masalah tentang tata ruang kawasan Kendeng, dengan anggota perwakilan berbagai dinas di Jawa Tengah serta para pakar dari berbagai perguruan tinggi di Jawa. Forum ini didirikan pada tahun 2011 sebagai bentuk kepedulian Universitas Diponegoro pada pembangunan di kawasan karst Kendeng.

Menurut seorang informan lain dari kalangan akademisi, Eko Haryono, seorang ahli karst yang juga Ketua Program Studi Geografi dan Ilmu Lingkungan Universitas Gadjah Mada, karst selalu berasosiasi dengan sumber air. Sekalipun tampak kering di atasnya, di lereng bukit karst pasti terdapat mata air dengan debit luar biasa. Bahkan, menurutnya, air dari karst ini memasok kebutuhan air penduduk dunia sekitar 25 persen. Informan ini aktif dalam kegiatan-kegiatan terkait penelitian karst dan terlibat dalam pembuatan kebijakan tentang kawasan karst.

Menurut Suara Merdeka (17 Juni 2012), kandungan air di balik keringnya kawasan karst adalah sumber kehidupan bagi warga sekitar. Air di balik pegunungan karst ibarat harta karun. Tak semuanya muncul di permukaan dan mudah dijangkau. Membutuhkan penelusuran gua untuk mengetahui dari mana datangnya dan ke arah mana air mengalir. Secara garis besar, air datang dari hujan yang jatuh ke permukaan karst yang berpori dan bercelah. Ada yang membentuk bebatuan gamping melalui proses karstifikasi. Ada juga yang menetes dan jatuh membentuk danau serta sungai kecil.

Yang menarik, sungai bawah tanah itu kerap kali tak bisa ditelusuri dari awal sampai akhir. Penelusuran sungai bawah tanah kerap harus dikombinasikan dengan teknik menyelam karena ketika air masuk ke dalam lubang 
kerap kali antara permukaan air dan dinding gua menyatu. Kekayaan air bawah tanah di seluruh Indonesia belum seluruhnya terpetakan. Padahal, peta ini penting sebagai salah satu dasar mengklasifikasikan pemanfaatan kawasan karst. Dengan demikian masih dipertanyakan, bolehkah kawasan karst ditambang ataukah harus dilindungi?

Selain kekayaan fisik, kawasan Sukolilo juga menyimpan kekayaan flora dan fauna, serta kekayaan budaya yang penting bagi masyarakatnya, sebagaimana pendapat Jamari, dosen Biologi, MIPA, Undip, yang menyatakan bahwa berdasarkan pengamatan langsung di lapangan dan penelaahan data yang ditemukan dalam penelitian, dapat dikemukakan Kawasan Kendeng merupakan wilayah yang subur dan produktif.

Jamari juga menulis (2011) dalam laporan penelitiannya, antara lain:

(a) Kawasan Tambakromo dan Sukolilo sekitar Pegunungan Kendeng mempunyai kekayaan sumberdaya hayati yang cukup potensial. Kekayaan ekosistem berupa lahan hutan jati, lahan pertanian berupa sawah dan tegalan, serta kawasan pemukiman, merupakan ekosistem yang lengkap. Berbagai jenis kekayaan species tumbuhan meliputi tanaman perkebunan hutan jati, tanaman pangan, tanaman obat, obatan, pakan ternak, kayu bakar dan tanaman liar lainya dan berbagai jenis fauna yang ada. Kekayaan hayati beserta lingkunganya di kawasan tersebut seharusnya cukup untuk menopang kehidupan masyarakat sekitar.

(b) Potensi kekayaan hayati yang dimiliki dan pemanfaatanya masih belum banyak terungkap, sehingga perlu penelitian lebih lanjut dan upaya upaya untuk mengelola kawasan tersebut menjadi lebih berhasilguna dan lebih produktif untuk menunjang pendaptan daerah dan meningkatkan kesejahteraan masyarakat.

(c) Selain kaya akan sumberdaya alam kawasan ini juga memiliki situs-situs keramat yang berkaitan dengan sejarah dan keberadan di wilayah tersebut. Situs keramat tersebut juga menjadi habitat beberapa jenis flora yang jarang ditemukan di tempat lain di kawasan Punungan Kendeng, keberadaan situs tersebut harus dipertahankan.

(d) Kawasan Pegunungan Kendeng dengan potensi keanekaragaman hayati yang cukup besar, ditambah dengan kondisi alamnya yang cukup menarik, antara lain banyak gua-gua di kawasan kars, sumber mata air, dan situs situs yang banyak terdapat di kawasan Kendeng. Maka kawasan Kendeng sesuai untuk dikembangkan menjadi kawasan wisata pendidikan, wisata ritual, ekowisata atau agrowisata.

Akan tetapi pemerintah dan dunia bisnis juga mempunyai kepentingan atas wilayah perbukitan karst yang sarat kepentingan ini. Beberapa pabrik semen berusaha mendapatkan ijin penambangan di wilayah tersebut, karena batu gamping merupakan bahan baku utama pembuatan semen. Sementara itu, atas nama pembangunan, pemerintah juga berusaha agar keinginan pabrik semen tersebut dapat terlaksana.

Masyarakat lokal menganggap bahwa kebijakan Peraturan Gubernur Jawa Tengah Nomor 128 Tahun 2008 tentang Penetapan Kawasan Lindung Karst Sukolilo dikeluarkan untuk mensahkan rencana pembangunan pabrik semen di kawasan Kecamatan Sukolilo, karena kemudian dijelaskan bahwa ada wilayah-wilayah tertentu yang bisa ditambang di wilayah tersebut. Kelompok yang menentang dengan keras kebijakan penambangan adalah kelompok masyarakat asli Sedulur Sikep yang lebih dikenal sebagai kelompok Samin, karena merupakan keturunan Mbah Samin Surosentiko.

Kelompok yang mempunyai sistem budaya sendiri yang khas dan unik ini kemudian menjadikan media massa sebagai partner untuk menyuarakan dengan keras perlawanan mereka terhadap rencana pembangunan pabrik semen, dibantu oleh para pegiat pelestarian lingkungan. Salah seorang pemimpin formal terkemuka kelompok Sikep ini, Gunretno, menyatakan dalam 
wawancaranya bahwa pengelolaan lingkungan di Kendeng seharusnya diperuntukkan untuk kawasan pelestarian alam, karena lingkungan alam di Kendeng harus dijaga agar tetap dapat memberikan manfaat secara berkelanjutan. Gunretno juga sering muncul diwawancarai di media tv, koran, majalah, bahkan film-film pendek tentang lingkungan.

\section{Organizing (Pengorganisasian)}

Pelaksanaan kegiatan pengelolaan lingkungan suatu wilayah haruslah dilakukan secara efektif dan efisien, dalam arti masing-masing pihak yang terlibat dapat menjalankan tugasnya dengan baik dan bertanggungjawab. Yang terlibat dalam hal ini khususnya adalah pemerintah, yaitu dinas-dinas yang terkait dalam pengelolaan kawasan Kendeng Utara. Komitmen aparat dan implementor dalam pengelolaan lingkungan sangat diperlukan.

Dalam Peraturan Pemerintah Nomor 26 Tahun 2008 tentang Rencana Tata Ruang Wilayah Nasional, semua bentang alam karst dan goa termasuk dalam Cagar Alam Geologi (Pasal 60 ayat 2 poin $\mathrm{C}$ dan F). Cagar Alam Geologi dalam peraturan tersebut dimasukkan dalam Kawasan Lindung Geologi (Pasal 52 ayat 5), Kawasan Lindung Geologi sebagai bagian dari Kawasan Lindung Nasional (Pasal 51).

Secara hierarki, kedudukan kawasan karst dalam PP No. 26 tahun 2008 sangat jelas, yaitu merupakan bagian dari Kawasan Lindung Nasional. Namun, saat ini muncul berbagai peraturan dan rencana revisi peraturan yang memungkinkan perusahaan menambang di kawasan karst. Contohnya adalah perda-perda tata ruang di kabupaten-kabupaten yang berada di pegunungan Kendeng Utara.

Pegunungan Kendeng Utara merupakan hamparan perbukitan kapur yang telah mengalami proses-proses alamiah dalam batasan ruang dan waktu geologi. Produk dari dinamika bumi yang berlangsung dari masa lalu hingga saat ini telah menghasilkan suatu fenomena alam yang unik. Masyarakat menggantungkan hidupnya di Pegunungan Kendeng Utara. Di sisi lain, kekayaan alam berupa bentang alam karst menjadi incaran perusahan semen. Karst adalah bahan baku utama pembuatan semen. Pada titik inilah ketegangan muncul, yaitu pemanfaatan sumber daya alam (Kartodihardjo, 2012). Sebagai dosen di Institut Pertanian Bogor dan Ketua Himpunan Masyarakat Perhutanan Indonesia, dalam wawancaranya Hariadi Kartodihardjo menyatakan bahwa kondisi ketegangan-ketegangan pemanfaatan lingkungan dengan kekayaan sumberdaya ini merupakan suatu kondisi yang umum terjadi belakangan ini di seluruh wilayah Indonesia.

Menurut beberapa informan masyarakat di kawasan Sukolilo, banjir berulang-ulang terjadi belakangan ini $\mathrm{d}$ kawasan Kendeng. Dimulai dari tahun 2004, 2008, 2009, 2009, dan seterusnya kemudian terjadi banjir setiap tahun di kawasan Sukolilo. Kondisi yang belum pernah terjadi pada waktu hutan masih penuh tanaman Jati di era sebelum reformasi. Penggundulan hutan berdampak negatif terhadap kemampuan lingkungan untuk menyerap air di kawasan Sukolilo.

Ada beberapa kepentingan yang bersinggungan dalam pengelolaan kawasan karst di kendeng Utara ini. Pemerintah, swasta, dan masyarakat lokal yang didukung media massa. Masing-masing dengan kepentingan mereka, di satu wilayah yang sama, yaitu wilayah Kecamatan Sukolilo.

\section{Actuating (Pelaksanaan)}

Pembangunan harus dilaksanakan secara berkelanjutan. Dampak dari pembangunan yang tidak berkelanjutan dan tidak berwawasan lingkungan amat berpotensi berakibat pada kerusakan lingkungan, akibat penurunan daya dukung dan daya tampung lingkungan. Kegiatan pembangunan memang amat diperlukan untuk peningkatan kesejahteraan manusia, namun seharusnya pembangunan tersebut dilaksanakan secara berkelanjutan, mengacu pada kondisi alam, dan pemanfaatannya agar berwawasan 
lingkungan. Hal ini diyakini oleh sebagian informan, khususnya dari kelompok pro pelestarian lingkungan. Terbukti kemudian ketika PT Semen Gresik tahun 2008 berencana memperluas lahan garapannya ke sebelah barat, yaitu di wilayah Kecamatan Sukolilo ini , mereka harus berhadapan dengan penolakan warga yang cukup keras.

Ketegangan antara masyarakat dan perusahaan semen sudah berlangsung sejak tahun 2006. Saat itu PT. Semen Gresik (Persero) Tbk berusaha akan melakukan eksploitasi bentang alam karst di pegunungan Kendeng Utara, tepatnya di wilayah Kecamatan Sukolilo dan Kayen.

PT Semen Gresik berencana mendirikan pabrik semen di Kecamatan Sukolilo. Rencana pembangunan pabrik semen yang dikaji dengan studi AMDAL yang dilakukan PT. Semen Gresik (Persero) Tbk kerjasama dengan Pusat Penelitian Lingkungan Hidup (PPLH), Lembaga Penelitian Universitas Diponegoro (AMDAL, 2008).

Studi AMDAL dilakukan setelah KA ANDAL memperoleh Keputusan Kesepakatan KA ANDAL berdasarkan Surat Keputusan Gubernur Jawa Tengah Nomor: 660.1/ BLH.II/ 2701 tanggal 18 Desember 2008 dan Nomor 660.1/ BLH.II/ 2714 tanggal 23 Desember 2008.

Akan tetapi, rencana penambangan ini dianggap merugikan masyarakat karena terjadi praktik intimidasi, kampanye hitam terhadap tokoh-tokoh kunci hingga kriminalisasi 9 (sembilan) orang petani. Akhirnya, PT. Semen Gresik, Tbk gagal melakukan eksploitasi karena penolakan masyarakat.

Kegagalan rencana Semen Gresik di Kecamatan Sukolilo tidak menyurutkan niatan pabrik semen lainnya untuk memanfaatkan lahan galian di kawasan Pegunungan Kendeng Utara, kali ini di kecamatan tetangga Sukolilo, yaitu Kecamatan Tambakromo. Bagaimana nasib lingkungan kawasan Kendeng Utara ke depan nya? Masih menjadi pertanyaan semua pihak.

\section{PENUTUP}

\section{Kesimpulan}

1. Kebijakan pengelolaan kawasan karst Kendeng Utara di Kecamatan Sukolilo, Kabupaten Pati, Provinsi Jawa Tengah berujud beberapa kebijakan yang bertumpu pada ciri wilayah sebagai deretan pegunungan karst, yang merupakan bagian dari pegunungan yang membentang mulai dari Tuban di sebelah timur hingga Grobogan di sebelah barat. Kebijakan-kebijakan ini melindungi kawasan tersebut sebagai kawasan lindung, namun dengan memberikan keleluasaan kawasankawasan tertentu untuk penambangan, sehingga dikeluarkan beberapa kebijakan khusus untuk kawasan karst Sukolilo.

2. Pengelolaan lingkungan.

Pengelolaan lingkungan di kawasan Kendeng Utara di Kecamatan Sukolilo, dapat dilihat menurut POAC, yaitu: (1) Planning atau Perencanaan, mencakup kegiatan perencanaan dalam rangka pengelolaan lingkungan secara terpadu terhadap wilayah karst Kendeng Utara. Dibutuhkan semen untuk pembangunan fisik gedung, jalan, dan lain sebagainya, sehingga kepentingan industri semen harus terpenuhi, namun masyarakat juga memerlukan lahan untuk hidup; (2) Organizing (Pengorganisasian): ada beberapa kepentingan yang bersinggungan dalam pengelolaan kawasan karst di Kendeng Utara. Pemerintah, swasta, dan masyarakat lokal yang didukung media massa. Masing-masing dengan kepentingan mereka, di satu wilayah yang sama, yaitu wilayah Kecamatan Sukolilo; dan (3) Actuating (Pelaksanaan): terdapat dorongan pelaksanaan konservasi sumberdaya alam, dan meningkatnya peran stakeholders dan kelembagaan yang terlibat. Namun belum muncul pelaksanaan optimatisasi pemanfaatan sumberdaya alam secara efisien. 
Saran:

1. Kebijakan kawasan karst sebaiknya (1) mempertimbangkan keunikan keunikan kawasan karst, (2) Kondisi sosial ekonomi sebagian masyarakat yang masih bersifat tradisional seharusnya menjadi pertimbangan dalam pembuatan kebijakan; (3) dukungan publik perlu digalang oleh pemerintah untuk dilakukannya pembangunan yang seharusnya menguntungkan semua pihak, dan mengacu pada pembangunan berkelanjutan.

2. Pengelolaan lingkungan: (1) Planning (Perencanaan), pembangunan berkelanjutan seharusnya dikedepankan, dengan menekankan pada terwujudnya pembangunan sosial di mana peranserta, dan keadilan menjadi bagian penting dalam pembangunan;

(2) Organizing (Pengorganisasian): ada beberapa kepentingan yang bersinggungan dalam pengelolaan kawasan karst di Kendeng Utara. Pemerintah, swasta, masyarakat, yang seharusnya dilakukan dengan mengedepankan win-win solution, misalnya dengan pelaksanaan zonasi; (3) Actuating (Pelaksanaan): harus dimunculkan pelaksanaan optimatisasi pemanfaatan sumberdaya alam secara efisien, dengan memanfaatkan teknologi yang ramah lingkungan, sekiranya pabrik semen jadi didirikan di wilayah Sukolilo.

\section{DAFTAR PUSTAKA}

AMDAL, 2008, Pembangunan Pabrik Semen PT. Semen Gresik Persero Tbk, Kabupaten Pati, Jawa Tengah. Semarang: PPLH Undip.

Asdak, Chay, 2004, Hidrologi dan Pengelolaan Daerah ALiran Sungai, Yogyakarta: Gadjah Mada University Press.

Brannen, Julia, terjemahan oleh Nuktah Arfawie Kurde dan Imam Safe'i, 2005, Memadu Metode Penelitian : Kuantitatif dan Kualitatif, cetakan ke VI, Yogyakarta: Pustaka Pelajar.
Faida, Lies Rahayu. Rina Laksmi Hendrati dan Hari Sukmono, 2011, Kajian Pengelolaan Karst Hijau di Kabupaten Gunung Kidul, Laporan Akhir Penelitian Kolaboratif, Yogyakarta: Fakultas Kehutanan, UGM.

Hadi, Sudharto P, 1996, Pembangunan Berkelanjutan Dalam Era Globalisasi: Peluang dan Tantangan Bagi Perguruan Tinggi, Pidato Dies Natalis Universitas Diponegoro ke 40, Semarang.

Haryono, Eko, dkk, 2010, Geomorfologi dan Hidrologi Kawasan Karst, Yogyakarta: Gadjah Mada University Press.

Jumari, 2011, Laporan Penelitian Lapangan Flora dan Fauna Kawasan Pegunungan Karst Kendeng, Semarang: tidk dipublikasikan

Kartodihardjo, 2012, Kartodiharjo, Hariadi dan Hira Jhamtani (ed), 2006, Politik Lingkungan dan Kekuasaan di Indonesia, Jakarta : Equinox.

Keban, Yeremias T, 2004, Enam Dimensi Strategis Administrasi Publik : Konsep, Teori dan Isu,

Yogyakarta : Penerbit Gava Media.

Nugroho, Hanan, 2003, paper Kuliah Umum di Magister Ilmu Lingkungan Universitas Diponegoro, Semarang.

Nugroho, Riant D, 2003, Kebijakan Publik: Formulasi, Implementasi, dan Evaluasi, Jakarta: Elex Media Komputindo.

Subandono, Pemanasan Global, Jakarta: Elex Media Komputindo.

Subarsono, AG, 2009, Analisis Kebijakan Publik: Konsep, Teori dan Aplikasi, Yogyakarta : Pustaka Pelajar.

Sugandhy, Aca, 1999, Penataan Ruang dalam Pengelolaan Lingkungan Hidup, 
Jakarta: P.T Gramedia Pustaka Utama.

Suhartadi. 2009, Evaluasi Pengelolaan Lingkungan Kegiatan Penambangan Batu Kapur PT. Sinar Alfa Fortuna (NAF) di Rembang.

Wuspada. Ratna, 2012, Implementasi Kebijakan Pelarangan Penambangan di Kawasan Karst Kabupaten Gunung Kidul”.

Winarto, Yudho, "Rupanya, Pemerintah Hanya Aktifkan Kembali Inpres No.2/2008", Kompas, 25 Juli 2011.

Gunretno, seorang tokoh masyarakat lokal, Suara Merdeka, 8 Agustus 2013
Kebijakan

Peraturan Pemerintah Nomor 26 Tahun 2008 tentang Rencana Tata Ruang Wilayah Nasional

Peraturan Menteri ESDM Nomor 17 Tahun 2012 tentang Penetapan Bentang Alam Karsts

Peraturan Gubernur Jawa Tengah Nomor 128 Tahun 2008 tentang Penetapan Kawasan Lindung Karst Sukolilo 